\title{
Growth of Balled-and-Burlapped versus Bare-Root Trees in Oklahoma, U.S.
}

\author{
Louis Anella, Thomas C. Hennessey, and Edward M. Lorenzi
}

Bare-root planting of trees has been promoted for community forestry projects because they can easily be hand-carried by planting crews or volunteers and are typically less expensive to purchase than balled-and-burlapped $(\mathrm{B} \& \mathrm{~B})$ trees. Because all of the soil is removed from a bare-root tree, shipping and handling costs are lower, resulting in up to a $33 \%$ to $50 \%$ cost reduction when compared with B\&B trees (Trowbridge and Bassuk 2004).

The disadvantage of bare-root trees is that having lost the protective soil cover, roots are exposed and prone to desiccation. To protect bare-root harvested tree roots, Buckstrup and Bassuk (2000, 2001) devised "the bare-root method," in which the root system is dipped in a hydrophilic gel immediately after harvesting and placed in a plastic bag to keep the roots moist during transport and short-term storage. Although Buckstrup and Bassuk (2001) have shown that many species can be successfully planted in Ithaca, New York, U.S., using the bare-root method, it has been suggested that bare-root planting is not a viable option in regions that experience severe heat and drought (Buckstrup 2004).

In Oklahoma, summers are typically hot and dry frequently resulting in $100 \%$ mortality if landscape plantings are not cared for properly. Irrigation is usually a critical cultural practice required for survival. One objective of this study was to determine if harvesting method (bare-root versus B\&B) affected survival or growth of irrigated landscape trees.

The authors have observed that even if newly planted trees survive, they are often stunted and unhealthy throughout their lives if they do not receive adequate water during establishment in Oklahoma. Irrigation (preferably automated drip irrigation) during the first 1 to 3 years is important for survival, proper establishment, and health in subsequent years. Marshall and Gilman (1998) showed that red maple (Acer rubrum) trees that were irrigated for 24 weeks after installation had two times more root mass penetrate the landscape soil than did trees irrigated for only 5 weeks. Even 5 years after transplanting, Gilman et al. (2003) found trees irrigated for 24 weeks had $50 \%$ greater root crosssectional area than trees irrigated for only the initial 5 weeks.

Although studies have investigated plant responses to fall versus spring planting (Harris and Bassuk 1994; Harris et al. 1996), no studies were found that tested winter versus spring planting. In Oklahoma, most species do not enter dormancy until midNovember (average killing frost of $-2^{\circ} \mathrm{C}\left[28.4^{\circ} \mathrm{F}\right]$ is 15 November in central Oklahoma, Oklahoma Mesonet); therefore, harvesting dormant plants begins in late November or December precluding fall planting. Englert et al. (1993) investigated the desiccation tolerance of bare-root red oak (Quercus rubra), Nor- way maple (Acer platanoides), and Washington hawthorn (Crataegus phaenopyrum) harvested at monthly intervals from September through April. Maximum desiccation tolerance occurred during January and February for all three species suggesting that winter harvesting and transplanting of bare-root trees may be advantageous where soil temperatures permit. Another objective of this study was to investigate the survival and growth of bareroot and B\&B trees harvested and transplanted in January compared with March.

\section{MATERIALS AND METHODS}

Twenty-four trees of three species, Platanus $\times$ acerifolia 'Bloodgood' (London plane), Acer $\times$ freemanii 'Jeffersred' (Autumn Blaze $^{\circledR}$ ), and Taxodium distichum (baldcypress), were obtained from Havenyield Tree Farm (Jones, OK) and randomly selected for one of four treatments: bare-root trees planted in winter, $\mathrm{B} \& \mathrm{~B}$ trees planted in winter, bare-root trees planted in spring, and $B \& B$ trees planted in spring. Trees were planted in a city park in Stillwater, Oklahoma.

Twelve trees of each species were harvested 9 January 2004 for winter planting and 12 of each species were harvested 11 March 2004 for spring planting. Trees of a species were harvested from the same nursery block, were randomly assigned to be harvested bare-root or $\mathrm{B} \& \mathrm{~B}$, and were approximately $40 \mathrm{~mm}$ (1.6 in) in caliper (measured $15 \mathrm{~cm}$ [6 in] above the ground). The B\&B trees were dug with a Dutchman 300(I) $75 \mathrm{~cm}$ (30 in) tree spade (Dutchman Industries Inc., Brougham, Ontario, Canada) mounted on a skid steer and placed in preformed wire baskets lined with burlap. The bare-root trees were dug with a Diversified Products Marketing (Davenport, NE) U-blade mounted on a skid steer. Roots of the bare-root trees were then dipped in a hydro-gel (Finn ${ }^{\circledR}$ A1000B, Fairfield, OH) and placed in a plastic bag as described by Buckstrup and Bassuk (2001) and referred to as the "bare-root method." The hydro-gel concentration was 4.7 $\mathrm{mL} / \mathrm{L}(0.6 \mathrm{oz} / \mathrm{gal})$ of water.

Mean annual rainfall for Payne County, Oklahoma, is $94.2 \mathrm{~cm}$ (37.7 in). Annual rainfall for Payne County, Oklahoma, in 2004 was near average $(94.7 \mathrm{~cm}$ [37.9 in]) and in 2005 was $18 \%$ below average (77 cm [30.8 in]) (Mesonet 2007). Rainfall is not seasonally well distributed and summer droughts are common.

After harvesting, bare-root and B\&B trees were transported to Stillwater, Oklahoma, where they were stored in the equipment bay of a metal building for 5 days to simulate planting delays frequently encountered by a municipality such as scheduling delays, weather delays, or other obstacles. On 14 January 2004 and 16 March 2004, the trees were transported to Babcock Park, 
Stillwater, Oklahoma. The baldcypress were planted in the lowest section of the planting area in an Ashport silty clay loam, occasionally flooded. The other trees were planted on slightly higher ground in a Teller loam.

Trees were hand-watered immediately after planting and after the spring planting, a drip irrigation system was installed for all trees. Each tree was watered with a 2 gal per hr Rain Bird ${ }^{\circledR}$ (San Diego, CA) Xeri-BugTM emitter for $4 \mathrm{hr}$ three times per week. Irrigation was controlled with a Hunter ${ }^{\circledR}$ (San Marcos, CA) Smart Valve Controller.

Trunk diameter, $15 \mathrm{~cm}$ (6 in) above the soil surface, and diameter of the first branch, $2.5 \mathrm{~cm}$ (1 in) from the trunk, were measured for all trees on 18 May 2004 and 20 May 2005. Trunk and branch growth (2004 measurements subtracted from 2005 measurements) were calculated for each species. Average shoot growth was calculated by measuring the current-season growth of three randomly selected shoots on each tree. Measurements were taken on 5 August 2004 and 23 August 2005.

Six Autumn Blaze ${ }^{\circledR}$ trees were destructively harvested in January from the nursery; three were dug bare-root and three were dug B\&B. Soil was removed from the root systems of all six trees, samples were dried in an oven for 3 days at $25^{\circ} \mathrm{C}$ $\left(77^{\circ} \mathrm{F}\right)$, and root/shoot ratios were calculated.

The experimental design was a randomized block for each species. Treatments were a factorial combination of planting season (winter versus spring) and production method (bare-root versus $\mathrm{B} \& \mathrm{~B})$. Data were analyzed using analysis of variance with mean separation by t-test $(P<0.05)$.

\section{RESULTS}

All trees survived regardless of planting date or production method. No significant interactions occurred so data are presented as main effects by species for planting season and production method.

No differences in baldcypress trunk growth, branch growth, or shoot growth occurred between treatments for planting season (Table 1) or production method (Table 2).

London plane planted in spring had greater shoot growth in 2004 than those planted in winter (Table 1). Growth of London plane was not affected by production method (Table 2).

Autumn Blaze ${ }^{\circledR}$ planted in spring had greater trunk growth than those planted in winter (Table 1). Shoot growth in 2004 and 2005 was greatest when planted in spring. Balled-and-burlapped Autumn Blaze ${ }^{\circledR}$ had greater shoot growth in 2005 than bare-root trees (Table 2). Other measured growth parameters were not affected by production method.

Bare-root Autumn Blaze ${ }^{\circledR}$ trees harvested from the nursery had a greater $(P<0.05)$ root/shoot ratio than $\mathrm{B} \& \mathrm{~B}$ trees. The average root/shoot ratio for bare-root trees was $0.67,37 \%$ greater than the B\&B root/shoot ratio of 0.49 .

\section{DISCUSSION}

Baldcypress was selected for this study because it is a commonly grown tree that does well in poorly drained soils and tolerates flooding, conditions found at the planting site. It was also selected because Buckstrup and Bassuk (2001) rated it as a difficult species to transplant using the bare-root method. Yet in the current study, all trees survived and growth of bare-root and B\&B baldcypress was similar. These results suggest that although some species may be difficult to transplant bare-root in
Table 1. The influence of planting season on selected growth parameters for trees planted in January (winter) or March (spring) of 2004 and measured in August of 2004 and 2005. ${ }^{\mathrm{z}}$

\begin{tabular}{lll}
\hline & Winter & Spring \\
\hline Baldcypress & & \\
$\quad$ Trunk growth & $0.31( \pm 0.034)$ & $0.27( \pm 0.035)$ \\
Branch growth & $0.43( \pm 0.063)$ & $0.36( \pm 0.081)$ \\
Shoot growth 2004 & $11.5( \pm 1.12)$ & $10.8( \pm 1.38)$ \\
Shoot growth 2005 & $28.6( \pm 3.19)$ & $28.3( \pm 2.92)$ \\
& & \\
London Plane & & \\
Trunk growth & $0.41( \pm 0.22)$ & $0.24( \pm 0.019)$ \\
Branch growth & $0.25( \pm 0.035)$ & $0.31( \pm 0.038)$ \\
Shoot growth 2004 & $35.3( \pm 3.27)$ & $47.3( \pm 4.15)^{\mathrm{y}}$ \\
Shoot growth 2005 & $40.3( \pm 2.32)$ & $44.1( \pm 3.17)$ \\
& & \\
Autumn Blaze & & $0.31( \pm 0.014)^{\mathrm{y}}$ \\
Trunk growth & $0.24( \pm 0.017)$ & $0.35( \pm 0.041)$ \\
Branch growth & $0.32( \pm 0.068)$ & $44.4( \pm 5.08)^{\mathrm{y}}$ \\
Shoot growth 2004 & $25.4( \pm 3.08)$ & $53.9( \pm 3.22)^{\mathrm{y}}$ \\
Shoot growth 2005 & $44.7( \pm 3.46)$ &
\end{tabular}

${ }^{\mathrm{z}}$ All data presented in centimeters ( \pm standard error).

${ }^{\mathrm{y}}$ Significant difference $(P<0.05)$ between winter and spring means.

regions where there is not a need to rely on irrigation, when irrigation is used, the range of species that can be successfully planted bare-root may be expanded. Gilman (2001) found that $43 \%$ of live oak (Quercus virginiana) trees planted in Gainesville, Florida, died after receiving irrigation for only 5 weeks after transplanting, whereas all trees survived when irrigated for the entire summer.

London plane and Freeman maple were listed as species that Buckstrup and Bassuk (2001) had successfully planted bare-root. In this study, growth of bare-root and B\&B London plane were

Table 2. The influence of production method on selected growth parameters for trees planted in January (winter) or March (spring) of 2004 and measured in August of 2004 and $2005 .^{\mathrm{z}}$

\begin{tabular}{|c|c|c|}
\hline & Bare-root & $\mathrm{B} \& \mathrm{~B}$ \\
\hline \multicolumn{3}{|l|}{ Baldcypress } \\
\hline Trunk growth & $0.26( \pm 0.03)$ & $0.32( \pm 0.038)$ \\
\hline Branch growth & $0.41( \pm 0.079)$ & $0.38( \pm 0.067)$ \\
\hline Shoot growth 2004 & $10.9( \pm 1.45)$ & $11.6( \pm 1.03)$ \\
\hline Shoot growth 2005 & $31.7( \pm 3.48)$ & $25.2( \pm 2.11)$ \\
\hline \multicolumn{3}{|l|}{ London Plane } \\
\hline Trunk growth & $0.43( \pm 0.218)$ & $0.22( \pm 0.021)$ \\
\hline Branch growth & $0.32( \pm 0.036)$ & $0.24( \pm 0.036)$ \\
\hline Shoot growth 2004 & $38.2( \pm 4.5)$ & $44.4( \pm 3.54)$ \\
\hline Shoot growth 2005 & $43.6( \pm 3.27)$ & $40.8( \pm 2.23)$ \\
\hline
\end{tabular}

Autumn Blaze ${ }^{\circledR}$

Trunk growth

Branch growth

Shoot growth 2004

$0.27( \pm 0.02)$

$0.27( \pm 0.018)$

Shoot growth 2005

$0.33( \pm 0.065)$

$0.34( \pm 0.046)$

$31.6( \pm 4.56)$

$38.1( \pm 5.37)$

${ }^{\mathrm{z}}$ All data presented in centimeters $( \pm$ standard error).

${ }^{y}$ Significant difference $(P<0.05)$ between bare-root and balled-and-burlapped means. 
similar and only shoot growth in 2005 for Autumn Blaze ${ }^{\circledR}$ trees was different. Balled-in-burlapped Autumn Blaze ${ }^{\circledR}$ grew more than bare-root trees.

Most studies investigating the optimal season for transplanting compare fall with spring and survival and growth are often found to be species-dependent. Harris and Bassuk (1994) found that green ash (Fraxinus pennsylvanica) and tree lilac (Syringa reticulata) transplanted well throughout the spring or fall, but that scarlet oak (Quercus coccinea) and Turkish hazelnut (Corylus colurna) had greater survival rates when transplanted early spring or midfall but not late spring and early fall. In this study, there was no evidence to suggest that winter or spring planting was advantageous for baldcypress. Only shoot growth of London plane in 2004 was greater in spring than during winter, but the next year, growth was similar suggesting that planting season had little performance influence.

Autumn Blaze ${ }^{\circledR}$ planted in spring had greater growth for three of the four parameters measured, suggesting that spring planting was advantageous compared with winter planting.

In this study, trees dug bare-root with a U-blade had a $37 \%$ higher root/shoot ratio than trees dug with a tree spade B\&B. Watson and Himelick (1997) found that up to $90 \%$ of the root system is left in the soil when trees are dug by the traditional B\&B method, whereas Haug (1996) reported that trees dug bareroot had $200 \%$ more roots than trees dug B\&B. The greater root/shoot ratio of bare-root trees in this study did not result in greater growth.

Baldcypress, London plane, and Autumn Blaze ${ }^{\circledR}$ can be planted using the bare-root method described by Buckstrup and Bassuk (2001) with irrigation even where summer heat and drought create challenges for trees. Planting in spring has little, if any, benefit over planting in January in Oklahoma for the species studied.

These findings indicate that bare-root planting is not limited to cooler regions of the United States. Community forestry programs in the southern United States can benefit from the advantages offered by bare-root planting when drip irrigation is used. In this study, a crew of three people planted all the bare-root trees using a small tractor and a box blade in less time than a crew of five people working with a front-end loader could unload the B\&B trees from the trailer.

Acknowledgments. We thank the Oklahoma Urban and Community Forestry Council for funding this project and Mike Smith and Ioannis Oikonomakos for help with statistical analysis.

\section{LITERATURE CITED}

Buckstrup, M. 2004. Secrets laid bare. American Nurseryman Aug. 15:28-30.

Buckstrup, M.J., and N.L. Bassuk. 2000. Transplanting success of balled-and-burlapped versus bare-root trees in the urban landscape. Journal of Arboriculture 26:298-308.

2001. Creating the Urban Forest: The Bare Root Method. Urban Horticulture Institute, Ithaca, NY. 16 pp.

Englert, J.M., K. Warren, L.H. Fuchigami, and T.H.H. Chen. 1993. Antidesiccant compounds improve the survival of bare-root deciduous nursery trees. Journal of the American Society for Horticultural Science 118:228-235.

Gilman, E.F. 2001. Effect of nursery production method, irrigation, and inoculation with mycorrhizae-forming fungi on establishment of Quercus virginiana. Journal of Arboriculture 27:30-38.
Gilman, E.F., J. Grabosky, A. Stodola, and M.D. Marshall. 2003. Irrigation and container type impact re maple (Acer rubrum L.) 5 years after landscape planting. Journal of Arboriculture 29:231-235.

Harris, R.J., and N.L. Bassuk. 1994. Seasonal effects on transplantability of scarlet oak, green ash, Turkish hazelnut, and tree lilac. Journal of Arboriculture 20:310-316.

Harris, R.J., P. Knight, and J. Fanelli. 1996. Fall transplanting improves establishment of balled and burlapped fringe tree (Chionanthus virginicus L.). HortScience 31:1143-1145.

Haug, M.C. 1996. Increasing transplant success of bare-root street trees by minimizing water stress during handling. Cornell University, Ithaca, NY, MS Thesis.

Marshall, M.D., and E.F. Gilman. 1998. Effects of nursery container type on root growth and landscape establishment of Acer rubrum L. Journal of Environmental Horticulture 15:55-59.

Mesonet. 2007. The Oklahoma climatological survey. www.ocs.ou.edu (accessed 7/24/2007)

Trowbridge, P.J., and N.L. Bassuk. 2004. Trees in the Urban Landscape. Wiley, Hoboken, NJ. 207 pp.

Watson, G.W., and E.B. Himelick. 1997. Principles and Practice of Planting Trees and Shrubs. International Society of Arboriculture, Champaign, IL. 199 pp.

Louis Anella (corresponding author)

Horticulture and Landscape Architecture

Oklahoma State University

358 Agricultural Hall

Stillwater, OK 74078, U.S.

lou.anella@okstate.edu

Thomas C. Hennessey

Natural Resource Ecology and Management

Oklahoma State University

008C Agricultural Hall

Stillwater, OK 74078, U.S.

tom.hennessey@okstate.edu

Edward M. Lorenzi

Natural Resource Ecology and Management

Oklahoma State University

008C Agricultural Hall

Stillwater, OK 74078, U.S.

ed.lorenzi@okstate.edu

Résumé. Des tests de tirage ont été menés sur des Quercus virginiana 'SDLN' PP\#12015 Cathedral Oak ${ }^{\circledR}$ nouvellement plantés de $7 \mathrm{~cm}$ de calibre qui avaient été cultivés en pot, et ce afin de simuler une poussée par le vent sur neuf types de système de stabilisation d'arbres communément employés. La comparaison des différents systèmes s'est faite au moyen d'une mesure de la force requise pour incliner la motte de racines de $20^{\circ}$. Les systèmes Terra Toggle ${ }^{\mathrm{TM}}$, Brooks Tree Brace ${ }^{\circledR}$ et $2 \times 2 \mathrm{~s}$ ont permis un ancrage des mottes avec les plus grandes forces. Typiquement, les arbres stabilisés avec ces trois systèmes se sont brisés avant que le système lui-même ne lâche, ce qui indique que ces systèmes étaient efficaces. Les systèmes T-stakes, à goujons et Tree-Staple ${ }^{\mathrm{TM}}$ n'ont pas mieux performé que dans le cas des arbres du groupe témoin sans système. Les trois système testés, soient ArborBrace ${ }^{\circledR}$, Duckbill $^{\circledR}$ et rebar \& ArborTie ${ }^{\circledR}$ étaient statistiquement similaires entre eux et les arbres requéraient une plus grande force au bris que dans le cas de ceux du groupe témoin, mais ils étaient moins efficaces que les trois premiers systèmes qui ont été nommés précédemment. La direction du tirage 
n'avait aucune influence sur la force requise de bris avec chacun de ces systèmes.

Zusammenfassung. Wir unternahmen Zugversuche an neugepflanzten, containergezogenen Eichen mit $7 \mathrm{~cm}$ Stammumfang, um Windlasten bis zu Stärke 9 auszuhalten, die gewöhnlich bei Baumstabilisierungs- Systemen angelegt werden. Es wurde die maximal erforderliche Kraft zum Drehen des Ballens um $20 \%$ wurde zum Vergleich der Systeme verwendet. Terra Toggle, Brooks Tree Brace und $2 \times 2$ s hielten den größten Kräften stand. Typischerweise brachen die Bäume bevor diese drei Systeme versagten, was uns zeigt, wie stabil sie waren. TStakes, Holzpflock, und Tree Stable leisteten nichts besseres als die Kontrollbäume. Die drei getesteten Erdanker-Systeme, ArborBrace, Duckbill und rebar \& ArborTie lagen statistisch gleich und erforderten mehr Kraft als die Kontrollen, aber weniger als die Gruppe, die den stärksten Kräften statt hielt. Die Zugrichtung hatte keinerlei Einfluss auf das Versagen der untersuchten Systeme.
Resumen. Se llevaron a cabo pruebas en Quercus virginiana 'SDLN' PP\#12015, Cathedral Oak ${ }^{\circledR}$, recién plantados de $7 \mathrm{~cm}$. (2.7 pulg.) de diámetro, creciendo en contenedor, para simular la carga del viento en nueve sistemas de estabilización de árboles comúnmente utilizados en el paisaje. Fue usada la fuerza máxima requerida para rotar la bola de raíces en $20^{\circ}$ para comparar los sistemas. Terra Toggle ${ }^{\mathrm{TM}}$, Brooks Tree Brace ${ }^{\circledR}$, y anclaje de la bola de raíces $2 \times 2$ s, resistieron las tensiones más grandes. Típicamente, los árboles asegurados por estos tres sistemas se rompieron antes que los sistemas fallaran, indicando que fueron muy efectivos. T-stakes, clavijas, y Tree Staple ${ }^{\mathrm{TM}}$ no actuaron mejor que los controles no estacados. Los tres sistemas de cables empleados, ArborBrace $^{\circledR}$, Duckbill ${ }^{\circledR}$, y rebar \& ArborTie $^{\circledR}$ fueron estadísticamente similares y requirieron más fuerza para fallar que los controles, pero menos que el grupo que resistió las fuerzas más grandes. La dirección de estiramiento no tuvo influencia en la fuerza de falla para cualquiera de los sistemas de estabilización empleados. 